\title{
Strategic Environmental Assessment (SEA) in Tehran Comprehensive Plan of Transportation and Traffic: An Approach Toward Achieving Sustainable Urban Development Projects
}

\author{
Hamid Azizi ${ }^{1}$, Reza Ahmadian ${ }^{2}$, Saleh Ghorbani ${ }^{3} \&$ Mehrdad Daneshdost ${ }^{4}$ \\ ${ }^{1}$ Department of Architecture and Urban Planning, Urban and Regional Planning faculty, Shahid Beheshti \\ University of Tehran, Iran \\ ${ }^{2}$ Departments of Urbanism and Architecture, Central Tehran branch Branch, Islamic Azad University, Tehran, \\ Iran \\ ${ }^{3}$ Department of Urbanism and Architecture, Najafabad Branch, Islamic Azad University, Najafabad, Iran \\ ${ }^{4}$ Department of Urbanism and Architecture, Zanjan Branch, Islamic Azad University, Zanjan, Iran \\ Correspondence: Hamid Azizi, Department of Architecture and Urban Planning, Urban and Regional Planning \\ faculty, Shahid Beheshti University of Tehran, Iran. E-mail: Hazizi65@yahoo.com
}

Received: December 28, 2015

Accepted: January 14, 2016

Online Published: January 31, 2016

doi:10.5539/mas.v10n3p107

URL: http://dx.doi.org/10.5539/mas.v10n3p107

\begin{abstract}
Believe in environmental reform is one of the sources of urban planning and probably is the most important and stable ideology of it. Urban rapid advancement in all realms especially during last two decades led various urban designs to reinforce harmony of urban development. On the other hand, emerge of some contexts such as sustainability and need of adoptability of urban designs with environmental factors caused new terms to create such as strategic environmental assessment.in this study; the origin of theoretical model of Strategic Environmental Assessment (SEA) will be presented. Moreover the practical circumstances of mentioned model in sustainable urban designs will analyzed. Therefore, the process of urban development designs can be optimized and the appropriate system to reach sustainability can be introduced. Transportation and traffic comprehensive plan of Tehran is the case study of the research due to its importance and adoptability to the contents of sustainable development. So, the technique taken to gain information, categorize their factors which affect sustainability is the Delphi technique. In addition, ICOLD Matrix is used to analyze the strategies of transportation comprehensive plan of Tehran with the factors of sustainability. The results of present research conform that the Strategies of Transportation and traffic comprehensive plan of Tehran needs refinement to reach the factors of sustainability. On the other hand, the process of SEA in planning period to achieve sustainable and optimum strategies is considered inevitable.
\end{abstract}

Keywords: SEA, sustainable urban designs, Tehran comprehensive plan of transportation and traffic, ICOLD Matrix

\section{Introduction}

Cities as a plan of population density are the place of various environmental challenges. Cities, especially metropolises are facing unbalanced environmental condition in developing economic circumstance. Meanwhile, their all mutual point is the inequality and unbalances in the nature [1]. Believe in the environmental development is the base of urban planning ideology and the most constant of them [2]. Cities rapid growth in recent century, especially in recent decade led urban design to help urban development to make a harmonic situation. Therefore, industrial countries start to accomplish design for their cities as a pioneer. Although it was started late, but it contained same challenges in practice as western cases. The conceptual aspect of these issues can be found in the process of urban design making and performing. Lack of timing in plans, shortage of coherent management in local and national scale, lack of comprehension and relativeness between current situation and plans content in addition to the lack of sustainable indicators in performing and implementing phase of plans are the after-effect of such approach due to these problems in global scale, sustainability of urban designs in social, economic, and environmental aspects seemed significant to design-makers and decision-takers [3]. In fact, the necessity of environmental care with economic and social views is considered undeniable. So, 
avoiding traditional trend in urban planning and management, which pay little care to the environment, is an important step toward the possibility of urban designs.

Urban transportation is the key elements in urban and regional studies, that is why all goods transportation from one place to another can be done through urban transportation. However it has caused some problem such as chronic air pollution, lack of livability, water pollution, and the pollution of environment. According to recent international studies, 25 percent of the energy worldwide is used for transportation. Therefore, environmental effect of transportation must be taken into decision. Aren't appropriate decisions taken into account, the condition of mentioned sector would be more unsustainable based on the following reasons:

- Adverse effect on the quality of air which decrease the quality of urban life.

- Destruction of ozone layer and global warming.

- Noise pollution, traffic jam, therefore over-crowded cities [4].

Tehran is also one of these metropolises that experience rapid growth due to the concentration of people and activities which caused various environmental problems in addition to economic, social and physical problems. The main reason for such problem is in lack of environmental indicators consideration in various urban studied and designs in the realm of transportation. Immigration and population explosion in 1970s and 1980s causes rapid and runaway growth in the city. These issues made authorities to make a Tehran comprehensive plan of transportation and traffic (CPTT) in 2008 which was for decreasing urban problems of Tehran till the outlook of 2025. Accordingly, present paper tries to determine effective indicators on the sustainability of transportation more over it seeks to analyze the comprehensive plan of transportation and traffic of Tehran with SEA model to identify its capability with indicators of sustainability.

\section{Methodology}

The methodology of the study is descriptive-analytic. So at first, the concept of Strategic Environment Assessment (SEA) and its place in decision making of urban studies are identified. On the next step, effective indicators and factors on sustainability of Tehran CPTT (as the case study) are introduced (with Delphi method) in three different realms of social, economic and environmental. Then the strategies were assessed with adopted indicators; so, the model of ICOLD has been used in order to pair-wise analysis. The out-come of this step is the determinant of the strength and weak points of comprehensive plan in sustainable development. Therefore it's easy to filter strategies which based on sustainable development (Figure 1).

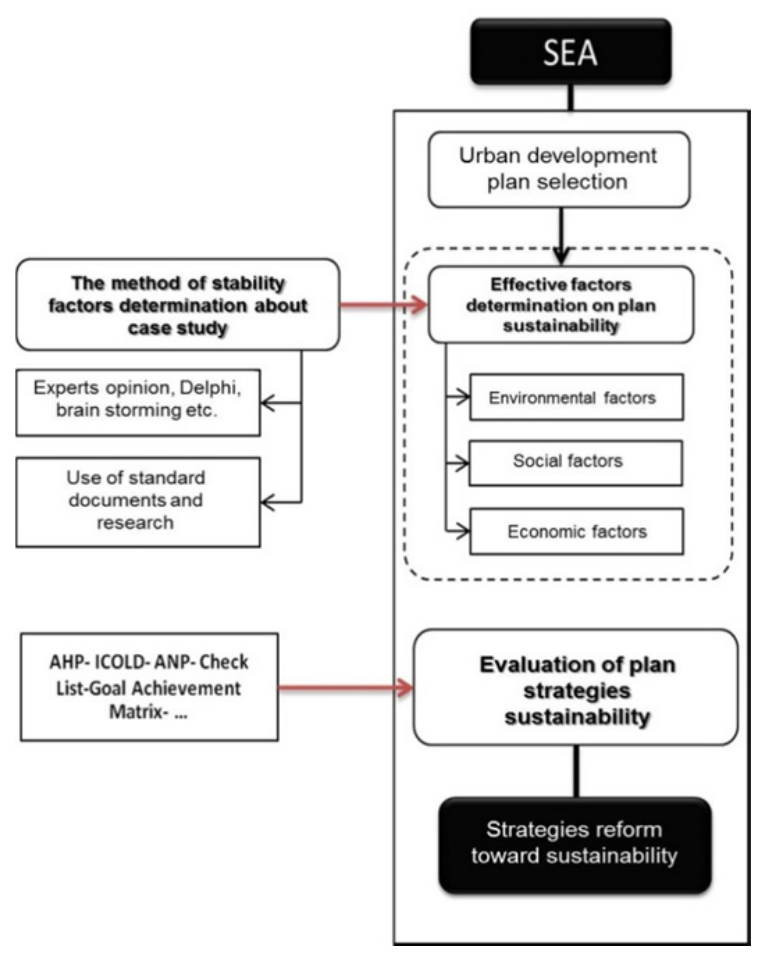

Figure 1. Proposal plan of SEA in urban development plans 


\section{Literature Review}

If the conference of Stockholm was the beginning of universal awareness about environment, the conference of Rio (1992) was the modern beginning in international movement toward environment protection. Accordingly, environment protection issue was in the headline of U.N agenda due to the welfare and health of people and ecosystem [5]. The result of international awareness about ecosystem and biology has been analyzed within different method and techniques such as environment-economic impact assessment, health impact assessment, risk analysis, strategic environmental assessment, which the last one is related to the subject of present study.

SEA and its legal importance were common after NEPA legislation in the US in 1969. This law made the government to analyze the environmental after- effect before performing any plan on human societies [6]. This law has transferred from The US to some other countries such as England, Canada, Australia, China etc. moreover; these countries contribute various legislations about environmental assessment, but the main purpose of them is to achieve a development plan based on environmental values protection. EIA is a policy based on law to identify positive and negative long-term and short-term impacts effects of governmental activities on the environment [7].

This analysis can partially help us to identify various impact of performing a plan or project in the society. As there was advancement in EIA (Environmental impact assessment) in the countries, this approach suffered from lack of literature in Iran. In the constitution of Iran any kind of activities harming the environment is banned, but lack of participation and coherency in the rules caused inefficiency in the law.

SEA is a planning method which was developed since 1980, discusses on the impacts of the strategic decision-making approaches that planners decide on general plans in public sector. It means, it can help planners as a decision-making tool in order to improve public participation in decision-making and therefore to help the government and local authorities [8]. It is systematic processes to assess environmental impacts of proposed policies, programs and primary plans to make sure that the strategies have been considering environmental issues, as well [9]. Main purpose and practical goal of SEA are as following:

- To make appropriate circumstance to reach sustainable development.

- To make suitable framework to make accurate decision based on environmental values.

- To increase participation in various countries against foreign threats.

- To make EIA more efficient through potential identification.

\section{Urban Development Plans Based on SEA Approach}

The experience of several years ago specially two last decades of 20th century, expresses fundamental change in the context of development which results in the sustainable development pattern. Coherency of economic, social, political and particular environmental aspects in sustainable development approach has been increasing in regional and international scale. In another word, development will be possible only if all of the indicators (considering environmental ones) are taken into account from the beginning of development plans and policies; however, it should contain sufficient weight in decision-making process of development plans.

In contrast to the traditional attitudes of planning which consider it, as a linear process of planning; modern attitudes of planning are based on phasic and comprehensive attitudes, which differ from stable approaches in policies and strategies [10]. In fact, this way of planning which is review-oriented can support any kind of flexible plans and their performance which is organized in the U.S, Britain and other developed countries.

The characteristics which distinct SEA from other evaluation and assessing models in the environmental point of view are as following [11]:

- First: To have comprehensive and long term perspective.

- Second: To have process of cycle and coherent.

- Third: To make an action plan for any plan, and programs.

According to the characteristics of SEA regarding the comprehensive and cyclic nature of planning process, there is the possibility of blending these two concepts. In another word, placing the position of SEA in planning process will be possible in that case (Figure 2). The function of strategic environment assessment doesn't officially need any complex techniques and methods but it needs the technique of scenario-writing of multi-functional analysis on risk management and decision -making with some statistical methods of social, economic and ecologic predictive methods.as mentioned by lots of researchers, the main advantage of SEA method is the prediction correction [12]. In fact this model can place different alternatives based on environmental capacities from the comprehensive point of view. 


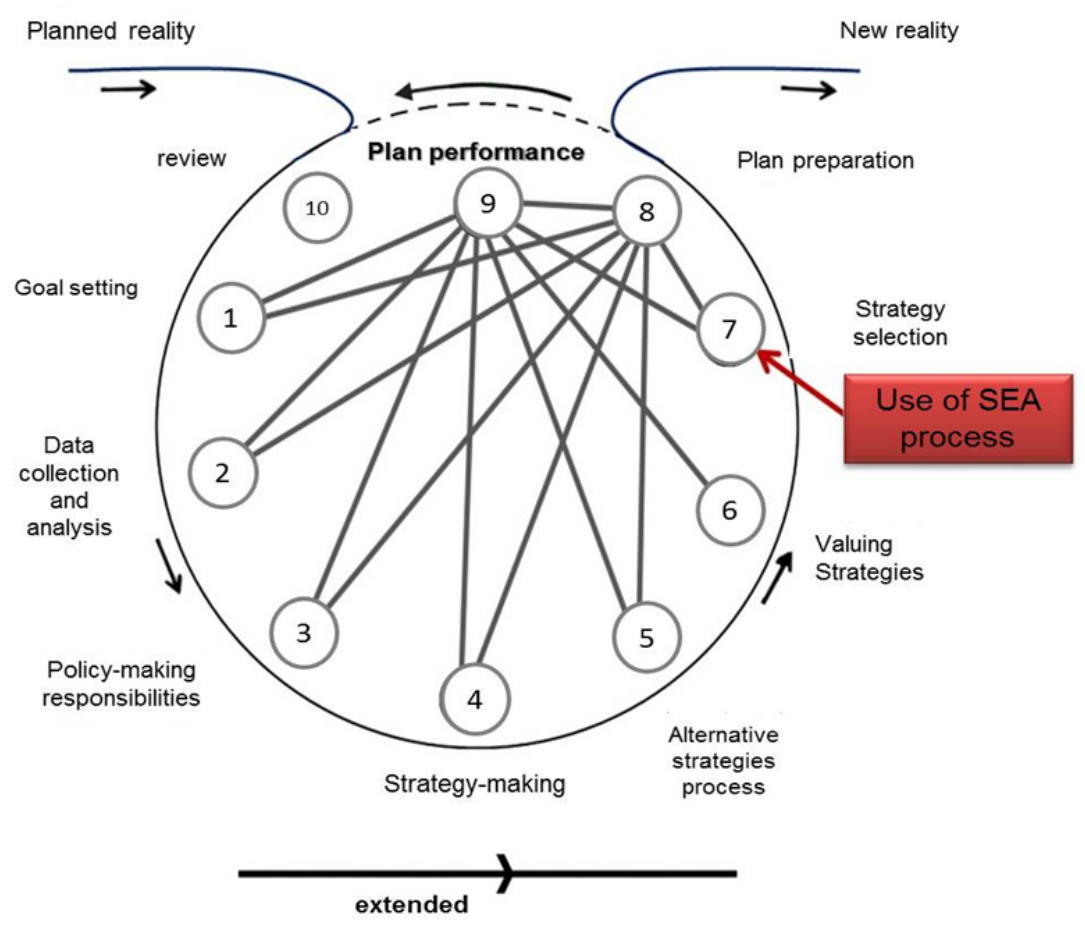

Figure 2. The interruption of SEA in cyclic extended urban planning

In fact this model can place different alternatives based on environmental capacities from the comprehensive point of view.

\section{The Process of Practicing Proposed Model}

\subsection{Urban Development Plan Selection (Tehran Characteristics and Comprehensive Plan of Transportation and Traffic)}

Tehran is the biggest metropolis in Iran and also Middle East with more than 7.8 million residents and 8.7 million people including daily visitors of the city which impose many problems to transportation system. Within last 10 years with increase in people's welfare, the number of urban trips have been rapidly increased. High range of trip rate, leads the burn fuel more than 12 million liters, which helps 2 million vehicles to pass inside transportation networks of the city. Bus and subway transportation systems in Tehran transfer 1 billion passengers and 250 million passengers, respectively [13]. These statistics can clearly show Tehran's problem in transportation realm, which needs a comprehensive plan indeed. Therefore, Tehran comprehensive plan of transportation and traffic of has been legislated. Figure 3 describes development of transportation sector till the outlook of 2024. 


\section{Vision}

Strategy

policy

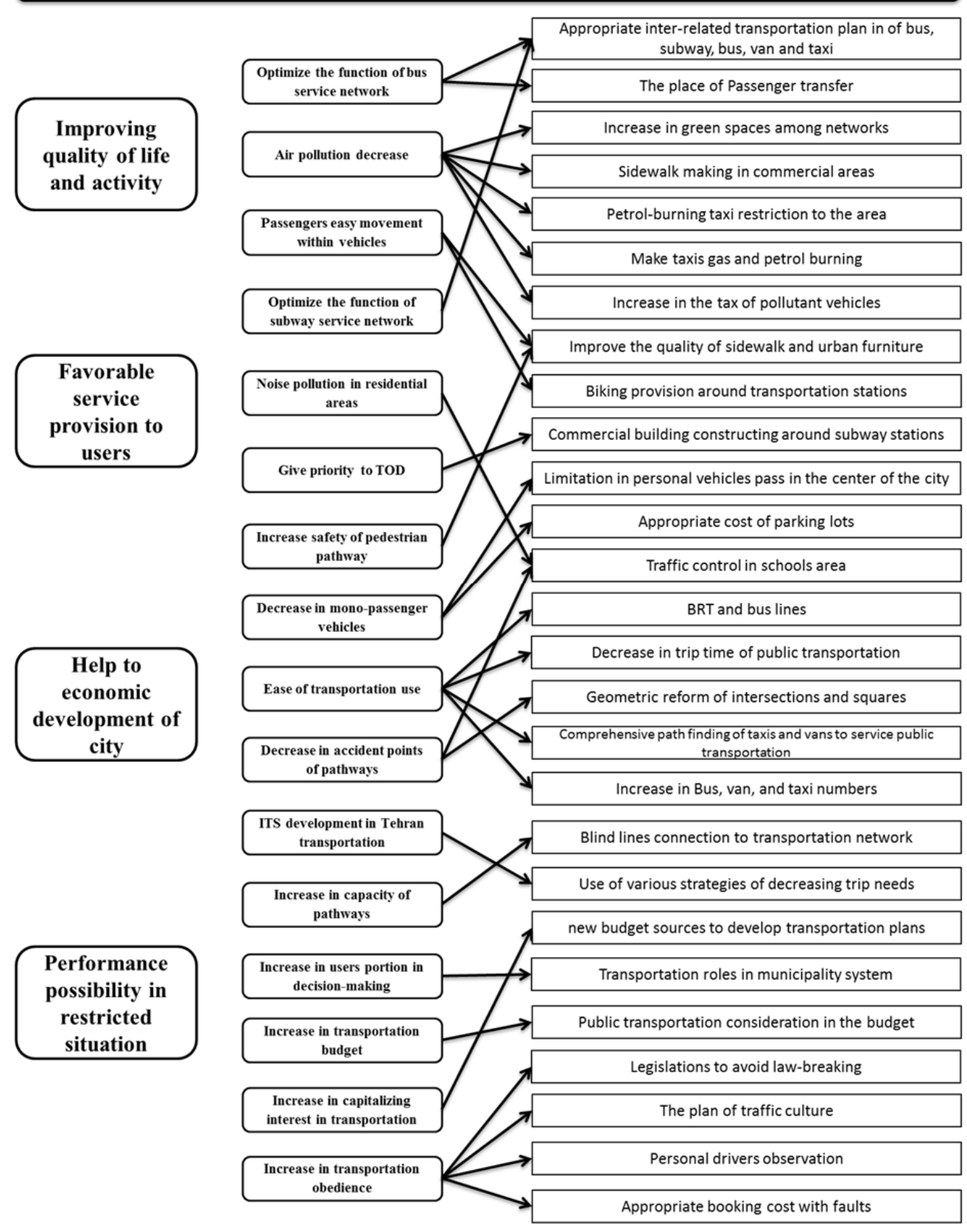

Figure 3. Visions, Strategies and policies of Tehran CPTT

\subsection{Determination of Effective Indicators on Plan Sustainability}

If we consider SEA as a method to achieve a sustainable pattern, it would be identified that the strategies and factors are arose from the context of sustainability. Therefore, researchers try to categorize the factors and indicators based on sustainable development in 3 main categories of economic, social and environmental; on the other hand researchers try to evaluate the strategies of Tehran comprehensive plan of transportation and traffic based on their feasibility. These factors and indicators are adopted from Delphi method with expert ideas. In another word, 20 questionnaires have been distributed through the internet from the viewpoints of various experts in the realms of urbanism, urban design, urban planning, urban traffic, sociology, and urban management. In the first phase of questionnaire, experts were asked to introduce effective factors on sustainable transportation. After receiving the opinions of experts and categorizing their indicators (Figure 4), experts were again asked to 
weight and value indicators and factors in second questionnaire on priority (table 1). The range of evaluation was in the scale of 9 quantitative of Thomas EL Saati.

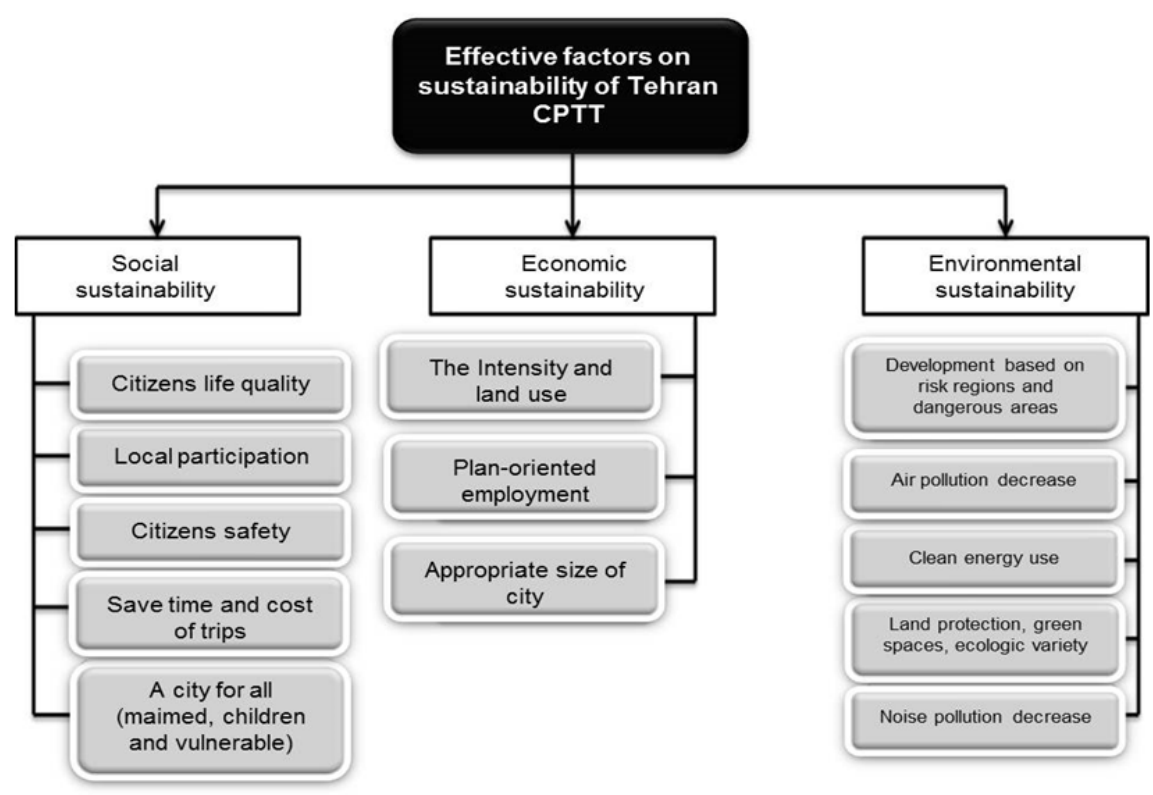

Figure 4. Effective indicators on sustainability of Tehran CPTT based on Delphi

The last point of each factor shows that which factor is consider significant to the experts. Great difference in the items scores shows a strategy more favorable than others.

Table 1. Final scores of CPTT effective indicators

\begin{tabular}{|c|c|c|c|c|c|c|c|c|c|c|c|c|c|}
\hline Real & \multicolumn{5}{|c|}{ environmental } & \multicolumn{3}{|c|}{ economic } & \multicolumn{5}{|c|}{ Social } \\
\hline factor & $\begin{array}{l}\text { Developm } \\
\text { ent based } \\
\text { on risk } \\
\text { regions } \\
\text { and } \\
\text { dangerous } \\
\text { areas }\end{array}$ & $\begin{array}{l}\text { Cle } \\
\text { an } \\
\text { ene } \\
\text { rgy } \\
\text { use }\end{array}$ & $\begin{array}{c}\text { Land } \\
\text { protec } \\
\text { tion, } \\
\text { green } \\
\text { space } \\
\text { s, } \\
\text { ecolo } \\
\text { gic } \\
\text { variet } \\
\text { y }\end{array}$ & $\begin{array}{c}\text { Noi } \\
\text { se } \\
\text { pol } \\
\text { luti } \\
\text { on } \\
\text { dec } \\
\text { rea } \\
\text { se }\end{array}$ & $\begin{array}{c}\text { Air } \\
\text { poll } \\
\text { utio } \\
\mathrm{n} \\
\text { dec } \\
\text { reas } \\
\mathrm{e}\end{array}$ & $\begin{array}{l}\text { Plan- } \\
\text { orient } \\
\text { ed } \\
\text { empl } \\
\text { oyme } \\
\text { nt }\end{array}$ & $\begin{array}{c}\text { Appr } \\
\text { opriat } \\
\text { e size } \\
\text { of } \\
\text { city }\end{array}$ & $\begin{array}{l}\text { The } \\
\text { Inte } \\
\text { nsit } \\
\text { y } \\
\text { and } \\
\text { lan } \\
\text { d } \\
\text { use }\end{array}$ & $\begin{array}{c}\text { Sav } \\
\mathrm{e} \\
\text { tim } \\
\mathrm{e} \\
\text { and } \\
\text { cost } \\
\text { of } \\
\text { trip } \\
\mathrm{s}\end{array}$ & $\begin{array}{c}\text { Citi } \\
\text { zen } \\
\text { s } \\
\text { safe } \\
\text { ty }\end{array}$ & $\begin{array}{c}\text { Loc } \\
\text { al } \\
\text { part } \\
\text { icip } \\
\text { atio } \\
\text { n }\end{array}$ & $\begin{array}{c}\text { Citi } \\
\text { zen } \\
\text { S } \\
\text { life } \\
\text { qua } \\
\text { lity }\end{array}$ & $\begin{array}{c}\text { A city } \\
\text { for all } \\
\text { (maim } \\
\text { ed, } \\
\text { childre } \\
\mathrm{n} \text { and } \\
\text { vulner } \\
\text { able) }\end{array}$ \\
\hline $\mathbf{w}$ & 0.46 & $\begin{array}{c}0.0 \\
71\end{array}$ & 0.051 & $\begin{array}{l}0.0 \\
32\end{array}$ & $\begin{array}{c}0 . \\
128\end{array}$ & 0.023 & 0.036 & $\begin{array}{l}0.0 \\
36\end{array}$ & $\begin{array}{c}0.0 \\
2\end{array}$ & $\begin{array}{c}0.0 \\
2\end{array}$ & $\begin{array}{c}0.01 \\
1\end{array}$ & $\begin{array}{l}0.0 \\
58\end{array}$ & 0.058 \\
\hline
\end{tabular}

The expert's opinion shows that the factor of "development based on risk region" with 0.46 and factor of "air pollution decrease" with 0.128 were respectively the most important factors. Other factors can be followed in table 1 .

\subsection{The Evaluation of Tehran Comprehensive Plan of Transportation and Traffic Sustainability}

Evaluation is a complex process seeking to find the effectiveness of a project or plan to determine its possibility and to find practical solution for efficient plan being predicted for future [14]. In this step all the strategies of Tehran comprehensive plan of transportation and traffic are dug out with its relation to the sustainability factors and been analyzed pair-wising. There are a lot of method and techniques that can be used in this step, AHP, ANP, 
goal achievement matrix, check list, ICOLD matrix and etc. for instance therefore, ICOLD matrix is used in this research.

\subsubsection{ICOLD Matrix}

This Matrix was first used by the international commission on large dams to determine its impact on the ecology of a region. Various impacts of each strategy in plan are analyzed with the intensity of impacts, frequency of impact. In ICOLD Matrix the possibility of impact is analyzed as table 2 [15].

Table 2. ICOLD matrix descriptive

\begin{tabular}{ll}
\hline $\begin{array}{l}\text { Impact } \\
\text { nature }\end{array}$ & Is expressed by + and - to show favorable and unfavorable impacts \\
\hline Impact & Major: impacts causing major change (3) \\
intensity & Moderate: impacts causing moderate change (2) \\
Impact & Minor: impacts causing minor change (1) \\
frequency & Temperate: impacts happening temperately after the action \\
Impact & Permanent: impacts happening permanently after the action \\
timing & All impacts don't take place at the same time. Some of them happen by the time of action while \\
\hline Source: International Commission on Large Dams (ICOLD) (2007).
\end{tabular}

Table 3. Quantitative descriptive of ICOLD matrix

\begin{tabular}{lllcc}
\hline Impact factors & Impact type & Abbreviation & Quantitative amount \\
\hline \multirow{2}{*}{ Impact intensity } & Major & 3 & 3 \\
& Moderate & 2 & 2 \\
& minor & 1 & 1 \\
& Impact nature & Positive & + & + \\
& Negative & - & - \\
& Tmpact frequency & Temperate & $\mathrm{T}$ & 0.7 \\
& Permanent & $\mathrm{P}$ & 1.5 \\
& Immediate & $\mathrm{I}$ & 1 \\
\multirow{2}{*}{ Impact timing } & Mid-term & $\mathrm{M}$ & 0.5 \\
& Long-term & $\mathrm{L}$ & 1.5 \\
\hline
\end{tabular}

Source: International Commission on Large Dams (ICOLD) (2007).

\subsubsection{Sustainability Evaluation Assessment of Tehran CPTT Strategies}

In this step of research, ICOLD matrix is used to evaluate Tehran CPTT strategies based on determined indicators. It should be declared that mentioned matrix is a blend of strategies and factors which is shown in table 2 in a case that a team of experts starts evaluating the sustainability of each strategy with the help of descriptive. If the impact of a strategy is identifies as blur, the cell would left vacant. In order to have quantitative amount of each strategy, there is a need of numerical descriptive which table 3 can be helpful in this way. The results of quantitative analysis are expressed in table 4. As shown in table 4, quantitative amount of each sustainability factor about Tehran CPTT. If we put factors weight away, this plan has got appropriate method and strategy to decrease air pollution. Risk region, however, suffers from lack of suitable strategy. 
Table 4. Strategies evaluation of Tehran CPTT

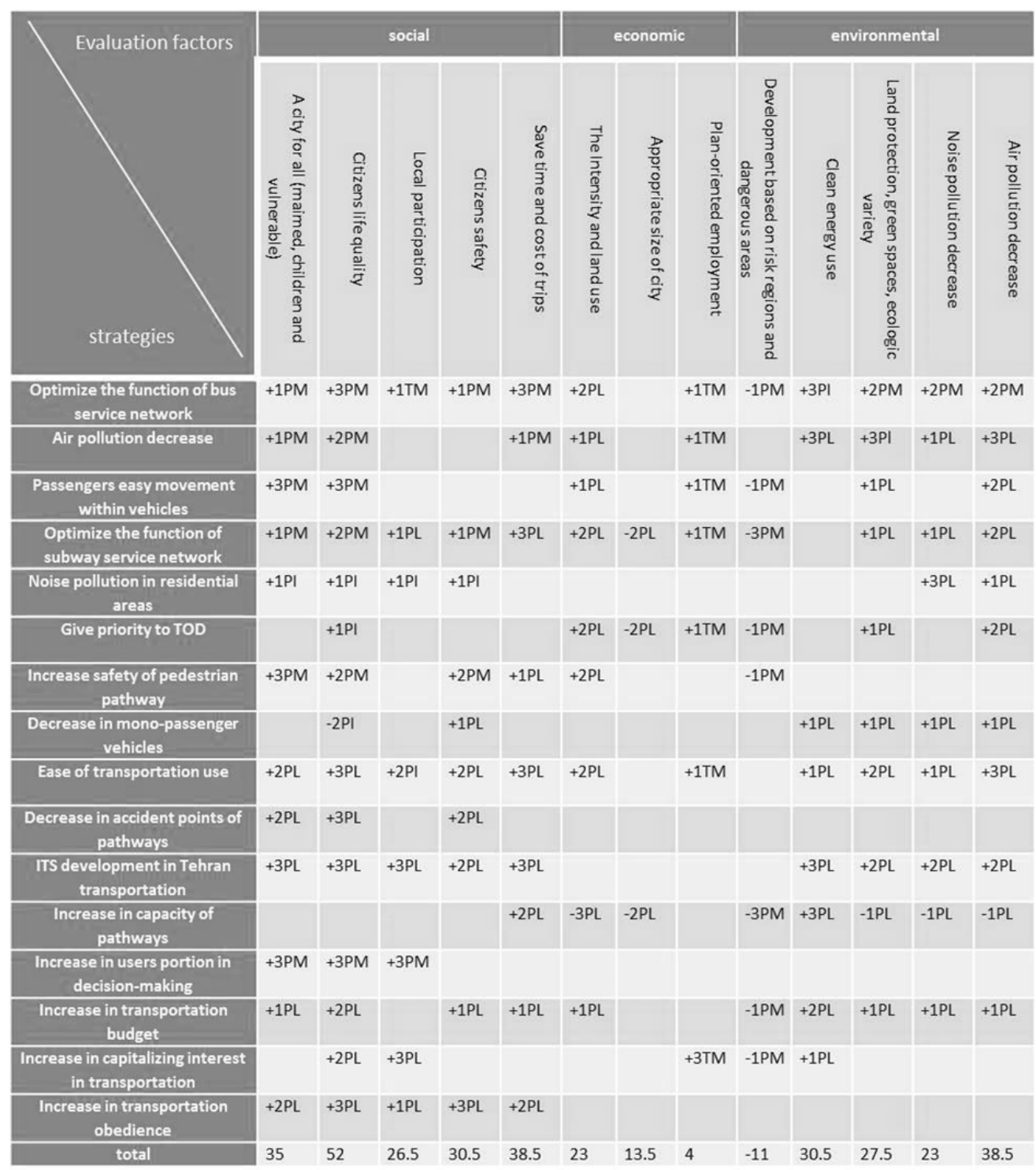

Now, each factor adopted from CPTT environmental evaluation (table 4) is multiplied to the weight (table 1). Outcome results are shown in Figure 5. 


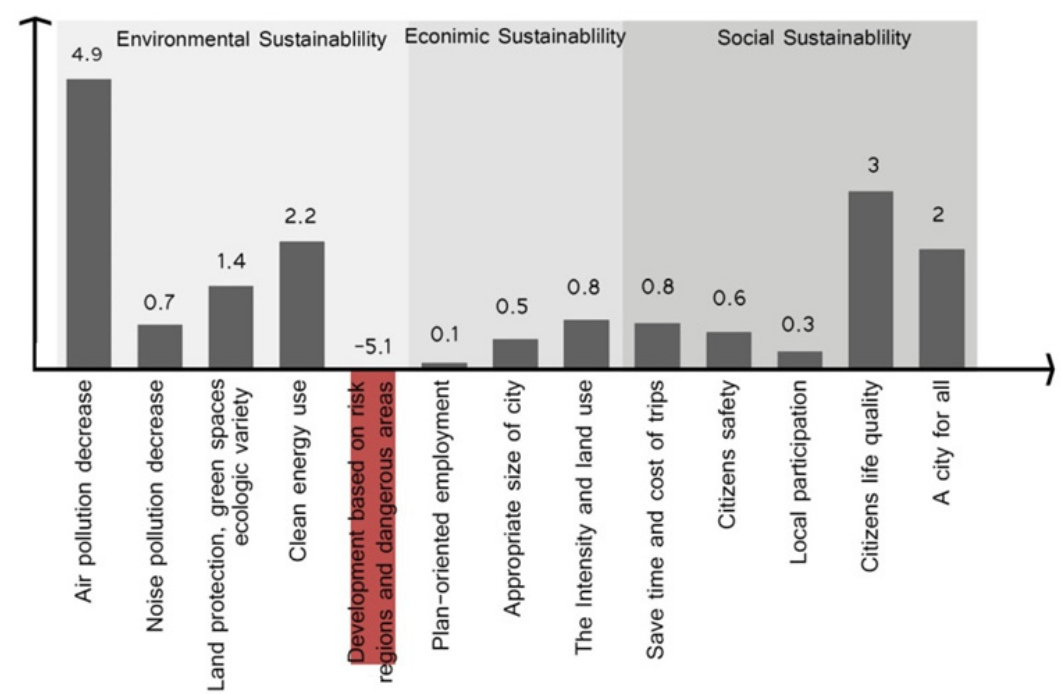

Figure 5. The amount of sustainability based on the factors in Tehran CPTT

Evaluation results confirm that Tehran CPTT strategies about the factor of "risk region-based development" need to be refined due to lack of appropriate transportation network considering region geology. Air pollution strategies are suitable though regarding the scores in evaluation. (Current pollution of Tehran doesn't reject the results. Enough consideration in Tehran CPTT has taken into account about air pollution.) Having the theory of strategies acceptance as score 2 , all of strategies grading under 2 must be refined and filtered.

Was the SEA by the time of plan preparation, it is obvious that more effective strategies and consequently better feedback from people would take place. Thus, sustainability indicators regarding in traditional planning of decision-making in urban development seem significant.

\section{Conclusion}

Urban and regional development plan SEA sounds significant as sustainable development approach is essential nowadays which should be considered in all phases of urban planning and design. The main results and achievements of the research are as following:

- To present suitable method of development strategies evaluation from the environmental viewpoint. Although the level of environmental studies is high in Iran, but it needs to be practical in decision-making and decision-taking of development plans.

- To blend the processes of SEA and use of experts knowledge to evaluate the sustainability amount of Tehran CPTT strategies and to determine faults of plan to be refined.

- To prepare indicators and factors for development plans evaluation in urban or even regional scale to reach a sustainable form.

- To make governmental organizations to participate and use of participations methods in evaluation can lead environmental problems emission.

- To determine the need of Tehran CPTT to be reformed in the level of strategies approved by Delphi method.

- To present a practical example of SEA in urban planning of Iran as the main achievement. It can be the beginning of planning improves in Iran considering environmental restriction in urban and regional planning. Therefore, this phase of study can be effective and useful.

\section{References}

Abdolhossein, V. Z. (1999). Environment determination. The publishment of wildlife and nature of Iran.

Daneshpour, Z. A. (2008). Literature of planning theories with emphasis on urban planning. Shahid Beheshti University press.

Ewing, R. (1997). Is Los Angeles-Style Sprawl Desirable. Journal of the American Planning Association, 63(1), 107-126.

Joudi, P. (2012). Regional development plan evaluation by the use of SEA. Master of Art dissertation, Shahid Beheshti University, Iran. 
Kiakjori, S. (2007). Rural develoment analysis and observation: experiences from asia.International Commission on Large Dams (ICOLD), World Register of Dams, ICOLD, Paris. Retrieved from $\mathrm{http}: / /$ www.icold-cigb.net

McCluskey, D., \& Joao, E. (2010). The promotion of environmental enhancement in Strategic Environmental Assessment. Environmental Impact Assessment Review Press.

Monavari, M. (2005). Environment impacts assessment. Mitra press, Tehran, Iran.

Noble, B. F. (2002). The Canadian experience with SEA \& Sustainability. Elsevier Inc.

Paridario, M. (2007). Strategic Ebvironmental Assessment Good practice Guide. Lisbon, Portuguese Environment Agency Amadora.

Sadler, B., \& Verheem, R. (1996). Strategic Environmental Assessment Status: Challenges and Future Directions. Ministry of Housing, Spatial Planning and the Environment, Publication number54, The Hague, Netherlands.

Sutcliffe, A. (1980). The rise of modern urban planning 1800-1914. Mansell, London.

Yavari, A. R. (2008). The place of ecology and environment in sustainable development. University of Tehran press.

\section{Copyrights}

Copyright for this article is retained by the author(s), with first publication rights granted to the journal.

This is an open-access article distributed under the terms and conditions of the Creative Commons Attribution license (http://creativecommons.org/licenses/by/3.0/). 